\title{
Growth of Leuconostoc mesenteroides \\ NRRL-B523 in an Alkaline Medium: \\ Suboptimal pH Growth Inhibition of a Lactic Acid Bacterium
}

\author{
Barry F. Wolf, H. Scott Fogler \\ Department of Chemical Engineering, University of Michigan, 2300 Hayward \\ Street, Ann Arbor, Michigan 48109, USA; telephone: 734-763-1361;
}

fax: 734-763-0459; e-mail: sfogler@umich.edu

Received 14 May 2004; accepted 13 August 2004

Published online 11 November 2004 in Wiley InterScience (www.interscience.wiley.com). DOI: 10.1002/bit.20315

\begin{abstract}
Bacterial profile modification (BPM), a form of tertiary oil recovery, diverts water from the water-flooded high-permeability zone into the oil-bearing low-permeability zone. During field use, exopolymer-producing bacteria plug the high-permeability zone only in the immediate vicinity of the injection point (the near-well bore region). For effective BPM the plug must penetrate far into the formation. Slowing the specific growth rate, lengthening the lag phase, and slowing the polymerization rate are techniques that can prolong the onset of biopolymer gelation and extend the depth of the biological plug. In batch experiments, the growth of Leuconostoc mesenteroides NRRL-B523 was inhibited by the synergistic effects of high substrate loading and an alkaline $\mathrm{pH}$. Exponential growth was delayed up to $190 \mathrm{~h}$. It was observed that cell division was significantly retarded until the medium $\mathrm{pH}$, reduced by the acid byproducts of fermentation, reached a critical value of $6.79 \pm$ 0.06. A mathematical model was developed to describe the relationship between specific growth rate, lag time, and medium pH. (c) 2004 Wiley Periodicals, Inc.
\end{abstract}

Keywords: L. mesenteroides; growth inhibition; bacterial kinetics; suboptimal $\mathrm{pH}$; bacterial profile modification

\section{INTRODUCTION}

Water-flooding, a common oil-field recovery technique that can increase reservoir productivity after the completion of primary recovery, uses injected water to displace the remaining crude oil and sweep it toward the production well (Willhite, 1986). Primary and secondary techniques are able to remove up to $35 \%$ of the original volume of crude that is contained within the readily accessible high-permeability regions of an oil reservoir (Atlas and Bartha, 1998). Once

Correspondence to: H. S. Fogler

Contract grant sponsors: University of Michigan Cellular Biotechnology Training Program, National Institutes of Health; University of Michigan Industrial Affiliates in Flow and Reaction in Porous Media; Baker Petrolite; Chevron Petroleum Technology Company; Conoco Production and Research Division; Halliburton Services; Phillips Petroleum; PSVDAIntevep; Schlumberger; TotalFinaElf; NPUSA, Inc.

Contract grant number: TGM GM08353 the high-permeability zones become water-flooded, tertiary recovery methods can potentially recover an additional $14 \%$ of the total oil volume (Atlas and Bartha, 1998). One such technique that relies on the in situ production of a flowblocking polymer is termed bacterial profile modification (BPM) (Lappan and Fogler, 1994).

The successful implementation of BPM, a form of microbial-enhanced oil recovery (MEOR), requires the selective plugging of the water-flooded high-permeability zone of an oil reservoir. Once the high-permeability waterflooded zone is blocked by the production of bacteria and exopolymers that form a gel, water is injected into the lowpermeability oil-containing zone, and oil is displaced from the reservoir. Although in situ bacterial growth and biopolymer production has been successfully performed in the laboratory, the rapid growth of bacteria near the injection well bore is an operational problem that leads to a decrease in the depth penetration of injected nutrients (Cusack et al., 1987; Jenneman et al., 1984; Robertson, 1998; Taylor and Jaffé, 1990). In a previous study it has been suggested that lengthening the lag phase and reducing the specific growth rate are two methods of increasing the depth penetration of injected nutrients, and thus improving BPM (Wolf and Fogler, 2001). Lengthening the lag phase and maintaining the bulk-phase cell concentrations at a low level will facilitate bacterial transport to greater depths within the waterflooded zone. To achieve lag times that provide a significant delay of biopolymer production, L. mesenteroides has been grown in media containing high sucrose concentrations (reduced water activity) and an alkaline $\mathrm{pH}$. This study examines the time-varying change in medium $\mathrm{pH}$ and the existence of a medium $\mathrm{pH}$ (the critical $\mathrm{pH}$ ) at which the bacterial population begins exponential growth.

The surface characteristics of the porous matrix, the initial porosity and permeability, and the pore size distribution affect the rate and extent of bacterial deposition (Harvey and Garabedian, 1991; Raiders et al., 1986). The bulk cell concentration also has a significant effect on the rate at which a 
porous matrix may be plugged by deposition (Jang et al., 1983; Sarkar et al., 1994). Although flow-induced deposition can lead to a decrease in permeability, it has also been shown that, without the production of exopolymers in a highly permeable matrix, there is no change in system permeability (Lappan and Fogler, 1992).

Bacterial growth and exopolymer formation are mechanisms that lead to the formation of a biofilm, a composite structure that can offer significant resistance to flow within a porous matrix (Wilderer and Characklis, 1989). Once formed, an exopolymer biofilm can reduce the permeability of a porous matrix to as much as 1/1000 of its initial value (Lappan and Fogler, 1992). Although extensive reduction of permeability is desirable for bacterial profile modification, it must be controlled so that near-well bore plugging is avoided. Once formed, localized sections of a biofilm can be partially removed by shearing, sloughing, abrasion, predation, or chemical disruption, with shear removal being the process most influenced by the local flow conditions within a porous matrix (Brading et al., 1995). Because porous matrix biofilms have been shown to last for as long as 2 years, bacterial plug placement is a process that needs to be controlled (Kim and Fogler, 2000).

Although it is desirable to have a fundamental understanding of the influence of $\mathrm{pH}$ and water activity $\left(a_{w}\right)$, the water mole fraction, on bacterial metabolism, changes in cytoplasmic reaction networks, membrane transport properties, and chemical species transport constants are not fully quantifiable (Dilworth et al., 1999; Pichereau et al., 2000). Nevertheless, unstructured, unsegregated growth models have been shown to effectively describe the combined effects of a time-invariant suboptimal $\mathrm{pH}$ and water activity on specific growth rate (Cerf et al., 1996; Kalathenos et al., 1995; McMeekin et al., 1993; Presser et al., 1997). When growth medium properties are assumed to remain constant, predictive models can also accurately forecast lag times observed in batch reactors (Baranyi et al., 1993; McMeekin et al., 1993). When a growth parameter such as $\mathrm{pH}$ or $a_{w}$ varies during the lag phase, the existing empirical models fail. For these reasons, a model that can account for changes in bacterial growth phase as a function of environmental conditions is necessary.

\section{MATERIALS AND METHODS}

Leuconostoc mesenteroides NRRL-B523 (ATCC 14935) was obtained from the American Type Culture Collection (Rockville, MD) and placed in a $-80^{\circ} \mathrm{C}$ freezer for longterm storage. Every 30 days an aliquot was removed from the freezer, streaked onto agar plates prepared using Difco Lactobacillus MRS broth, grown for $18 \mathrm{~h}$, and stored at $4{ }^{\circ} \mathrm{C}$. Streak plates were discarded after 30 days of $4^{\circ} \mathrm{C}$ storage.

L. mesenteroides inoculum was prepared by transferring one colony from the streak plate into media containing $7.9 \mathrm{~g} / \mathrm{L}$ glucose, $7.9 \mathrm{~g} / \mathrm{L}$ fructose, and $10 \mathrm{~g} / \mathrm{L}$ Difco yeast extract solution diluted in a mineral salt solution. The min- eral salt solution contained $0.067 \mathrm{M}$ sodium acetate, $0.075 \mathrm{M}$ sodium chloride, $0.061 M$ ammonium chloride, $6.1 \times$ $10^{-3} M \mathrm{~K}_{2} \mathrm{HPO}_{4} \cdot 3 \mathrm{H}_{2} \mathrm{O}, 3.1 \times 10^{-3} M$ ascorbic acid, $4.1 \times$ $10^{-4} M \mathrm{MgSO}_{4} \cdot 7 \mathrm{H}_{2} \mathrm{O}, 4.0 \times 10^{-5} M \mathrm{MnSO}_{4} \cdot \mathrm{H}_{2} \mathrm{O}$, and $4.0 \times 10^{-5} M \mathrm{FeSO}_{4} \cdot 7 \mathrm{H}_{2} \mathrm{O}$. After $22 \mathrm{~h}$ of growth at $30^{\circ} \mathrm{C}$, $10 \mathrm{~mL}$ of inoculum was aseptically transferred to a 1000-mL side-arm Erlenmeyer flask containing $550 \mathrm{~mL}$ of the desired growth medium. The initial cell concentration was $7.5 \times 10^{6} \pm 0.1 \times 10^{6}$ cells $/ \mathrm{mL}$. The growth medium contained $10 \mathrm{~g} / \mathrm{L}$ Difco yeast extract, varying concentrations of sucrose, and varying concentrations of sodium hydroxide dissolved in the mineral water solution just described. All experiments used an identical lot of yeast extract.

The medium $\mathrm{pH}$ was measured using a Corning Model 476156 semi-micro $\mathrm{pH}$ combination electrode and an Oakton Model 510 benchtop $\mathrm{pH}$ meter. The $\mathrm{pH}$ probe was calibrated twice a day with $\mathrm{pH} 4.01,7.00$, and 10.01 buffers. When carefully calibrated, the $\mathrm{pH}$ probe is accurate to $\pm 0.02 \mathrm{pH}$ unit (Harris, 1987). The medium initial $\mathrm{pH}$ value was adjusted using $4 \mathrm{M}$ sodium hydroxide and $1 \mathrm{M} \mathrm{HCl}$; the medium $\mathrm{pH}$ value was not controlled after inoculation. Throughout this study, the term "initial $\mathrm{pH}$ " refers to the growth medium $\mathrm{pH}$ value immediately after inoculation.

Batch kinetics reactions were carried out in screw-top glass Erlenmeyer flasks fitted with a side-arm capped by a septum. Before inoculation, the batch reactors and media were autoclaved at $121^{\circ} \mathrm{C}$ for $15 \mathrm{~min}$ to ensure sterility. The contents of the batch reactor were unaltered during the course of the reaction except for the withdrawal of liquid samples and accompanying carbon dioxide gas dissolved in the growth medium. All batch reactions were conducted at a constant $30^{\circ} \mathrm{C}$ with constant mixing using a 1.5 -in. stir bar rotating at $120 \mathrm{rpm}$. Sealed batch reactors provided anaerobic growth conditions. During the reaction period, liquid samples were aseptically taken from the reactor upon inoculation and at intervals ranging from 10 min to $24 \mathrm{~h}$. The total cell count was measured using a Model ZF Coulter Counter fitted with a $30-\mu \mathrm{m}$ diameter aperture tube. Viable colonies were enumerated using the spread plate technique, with sterile phosphate-buffered saline solution used as a diluent.

The cell concentration data from batch growth experiments were fit to the modified Gompertz equation using the Levenberg-Marquardt method (Press et al., 1992; Zwietering et al., 1990). The modified Gompertz equation is as follows:

$$
y=A \cdot \exp \left[-\exp \left\{\frac{\mu \cdot e}{A}(\lambda-t)+1\right\}\right]
$$

where $y=\ln \left(N / N_{0}\right), A=\ln \left(N_{\infty} / N_{0}\right), e=2.718, t$ denotes the time in units of hours, $\mu$ denotes the specific growth rate in units of $1 / \mathrm{h}$, and $\lambda$ denotes the length of lag time in units of hours. $N$ is the cell concentration at any time during the experiment in units of cells $/ \mathrm{mL}, N_{0}$ is the initial cell concentration in units of cells $/ \mathrm{mL}$, and $N_{\infty}$ is the stationaryphase cell concentration in units of cells $/ \mathrm{mL}$. 
Water activity is calculated using Rault's law. Assuming an ideal solution of nonelectrolytes, the water activity of a solution containing $n_{w}$ moles of solvent and $n_{s}$ moles of solute is given as:

$$
a_{w}=\frac{n_{w}}{n_{w}+n_{s}}
$$

where water is the solvent and sucrose is the solute.

\section{RESULTS AND DISCUSSION}

To understand and model metabolic responses to an adverse medium, L. mesenteroides was grown in a variety of conditions in which two parameters were varied: $a_{w}$ and $\mathrm{pH}$. In a previous study, it was determined that increasing the sucrose concentration, and thus a lower $a_{w}$, reduced the specific growth rate and increased the lag time in $L$. mesenteroides batch fermentations (Wolf and Fogler, 2001). It was found that the change in lag time and specific growth rate increased linearly with decreasing $a_{w}$ and that, in combination with a suboptimal medium $\mathrm{pH}$, the lag time increased by an order of magnitude. Although bacteria are able to grow at approximately the same rate for a wide range of medium conditions (optimum conditions), a growth medium is considered suboptimal when there is a large deviation from the optimum growth dynamics (Pichereau, 2000). This study focuses on the suboptimal growth regime.

\section{Suboptimal Water Activity Effects}

To identify the region of suboptimal water activity, the sucrose concentration was varied while the initial $\mathrm{pH}$ was maintained near the maximum tolerable value. The maximum tolerable $\mathrm{pH}$ was determined to be 8.2 in earlier studies (Wolf and Fogler, 2001). Sucrose concentrations that induced lag times of $>100 \mathrm{~h}$ are indicative of a suboptimal growth regime (Fig. 1). To facilitate comparisons with current research, sucrose concentration has been

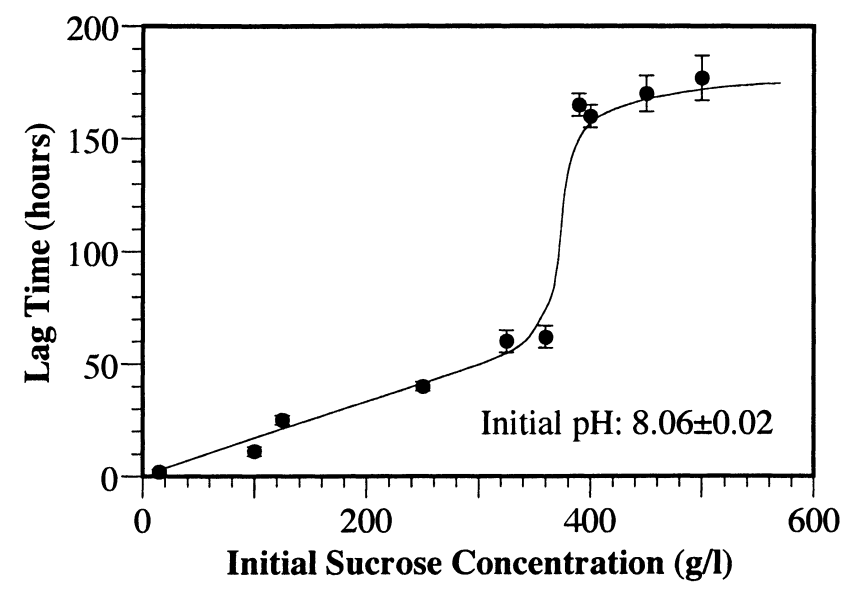

Figure 1. Initial sucrose concentration controls lag time. Error bars indicate $95 \%$ confidence intervals. transformed into water activity for the discussion of the present study's results.

The measured molality of each sucrose solution was used to calculate the corresponding initial $a_{w}$ using Eq. (2). An initial $\mathrm{pH}$ of 8.06 was chosen because of its proximity to the maximum tolerable $\mathrm{pH}$. Other $\mathrm{pH}$ values were tested (data not shown), but 8.06 afforded significant and repeatable results. The results, shown in Figure 2, indicate that there is a critical $a_{w}$ of 0.973 below which the lag time increases discontinuously from 60 to $160 \mathrm{~h}$. The specific growth rate measured during the exponential growth phase (Fig. 2) decreases in a linear fashion.

Although a small discontinuity in the specific growth rate has also been observed in Staphylococcus aureus by Scott (1953), an accompanying change in lag times has not been reported. These results indicate that there is a change in bacterial metabolism when at $a_{w}<0.973$. The long lag times observed at $a_{w}<0.973$ indicate that $L$. mesenteroides may be actively accumulating a compatible solute to combat the sucrose-induced osmotic gradient across the cellular membrane (Gouffi et al., 1998). Because intracellular solute accumulation is a prerequisite for exponential growth in a medium with a high osmolarity, protein synthesis may be delayed until the intracellular conditions have been adjusted (Christian and Hall, 1972). The increased osmotic stress experienced by $L$. mesenteroides may also lead to a change in gene expression; new metabolic pathways require energy that otherwise would be used to combat an adverse osmolarity (Pichereau et al., 2000).

\section{Suboptimal pH Effects}

To determine the effects of a suboptimal $\mathrm{pH}$ on L. mesenteroides growth, the initial $a_{w}$ was adjusted to a constant value of 0.960 while the initial $\mathrm{pH}$ was varied. An initial $a_{w}$ value of 0.960 was chosen because it afforded a significant and repeatable increase in lag time over a range of pH values (Wolf and Fogler, 2001). From previous studies on $L$. mesenteroides, it was determined that a medium $\mathrm{pH}$ of $>7.5$ was suboptimal because of an exponential increase

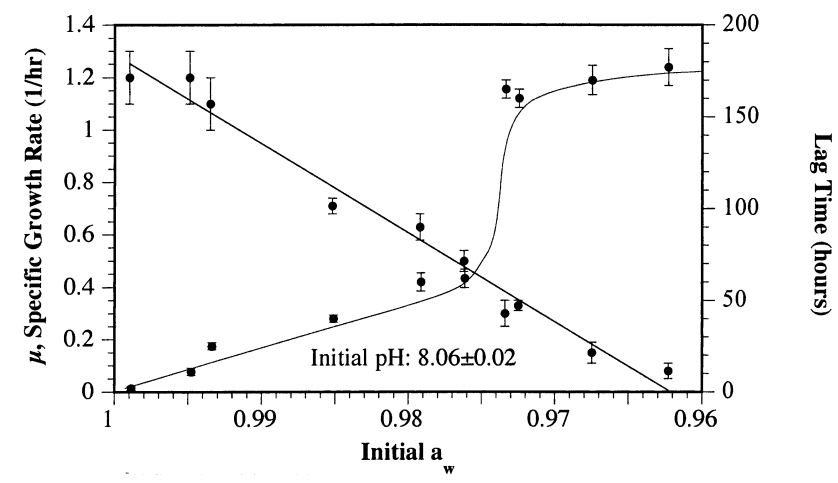

Figure 2. The specific growth rate varies linearly as a function of $a_{w}$ in conjunction with a discontinuity in lag time. Error bars indicate $95 \%$ confidence intervals. 
in lag time (Wolf and Fogler, 2001). This phenomenon has been examined in more detail in this study. In the suboptimal $\mathrm{pH}$ range, the $\mathrm{pH}$ begins to drop from its initial value as the bacteria produce lactic acid (Holzapfel and Schillinger, 1981) and carbon dioxide that dissolves and is protonated to form carbonic acid. The following was found: regardless of the initial suboptimal $\mathrm{pH}, L$. mesenteroides transitioned into the exponential growth phase when the solution $\mathrm{pH}$ was 6.79 with a $95 \%$ confidence interval of $0.06 \mathrm{pH}$ unit (Figs. 3 and 4). The lag phase duration increased with increasing initial $\mathrm{pH}$ because of the additional acid production required to reduce the solution $\mathrm{pH}$ to 6.79 . This transition $\mathrm{pH}$, herein designated the critical $\mathrm{pH}$, is a novel finding.

\section{Batch Growth Model}

Because of the inhibitory conditions of the growth medium used in this study, it was shown that the transition to the exponential phase can be delayed for up to $200 \mathrm{~h}$; however, cell growth was detected as the solution $\mathrm{pH}$ decreased toward a value of 6.79. According to Cooper's strict definition of the bacterial growth cycle, the lag phase is the pause in the bacterial growth cycle before mitosis begins (Cooper, 1991). The period of slow growth observed in this study does not strictly satisfy Cooper's definition of the lag phase; however, to simplify our discussion, we have chosen to describe this slow-growth stage as a lag phase.

After L. mesenteroides was inoculated into a medium with a suboptimal $\mathrm{pH}$ there was a linear increase in the cell concentration and an exponential increase in acid concentration (Fig. 5). Viable cell counts (data not shown) confirmed there was no cell death occurring during the lag phase. Furthermore, it was found that the specific growth rate during the lag phase decreased exponentially with respect to the initial, suboptimal medium pH (Fig. 6). The following combined mass balance and rate law equation

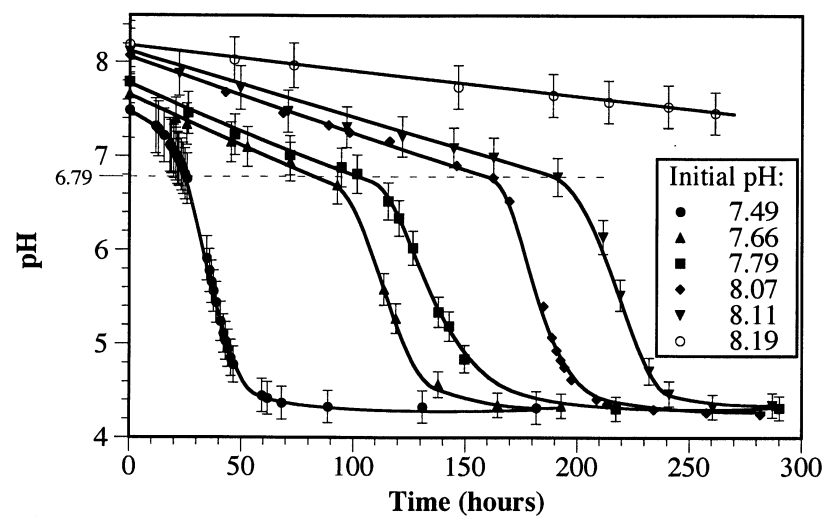

Figure 3. Medium $\mathrm{pH}$. Experiments were performed in duplicate and were in good agreement. A single representative experiment is shown for each condition. Error bars indicate $95 \%$ confidence intervals for triplicate pH measurement.

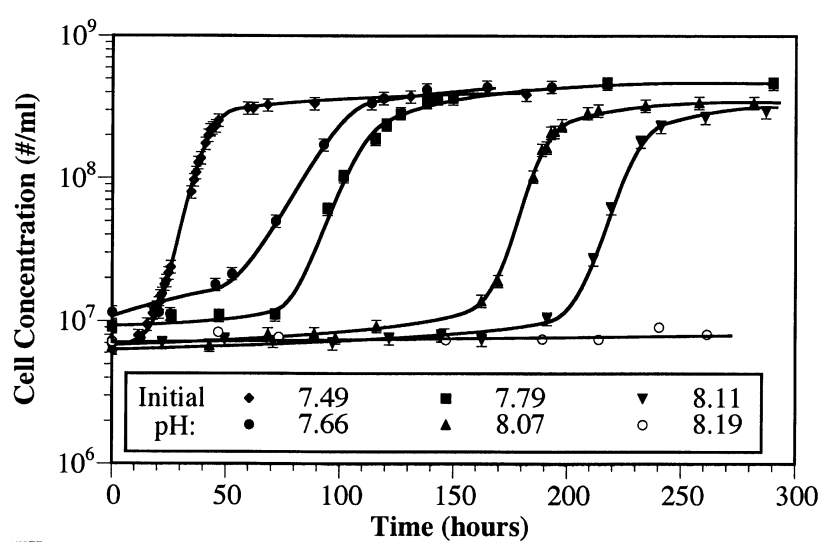

Figure 4. Bacterial growth at suboptimal $\mathrm{pH}$. Experiments were performed in duplicate and were in good agreement. A single representative experiment is shown for each condition. Error bars indicate $95 \%$ confidence intervals for triplicate cell concentration measurement.

accounts for growth during the lag phase based on experimental observation (Fig. 6):

$$
\frac{d C_{x}}{d t}=k_{1} C_{x}
$$

with the empirical relationship $k_{1}=2.13 \times 10^{15} \exp (-5.15$ $\left.\mathrm{pH}_{0}\right) \mathrm{h}^{-1}$, where $C_{x}=$ cell concentration (cells $/ \mathrm{mL}$ ), $t=$ time (h), $\mathrm{pH}_{0}=\mathrm{pH}$ measured at experiment start time.

During the lag phase, slow growth was accompanied by a slow rate of acid production that was observed to be growthassociated. The following acid generation rate equation is based on experimental observation:

$$
\frac{d C_{H^{+}}}{d t}=k_{2} C_{H^{+}}
$$

where $C_{H^{+}}$is acid concentration $\left(\left[H^{+}\right] / \mathrm{mL}\right)$, and $k_{2}=$ $\left(0.012+2.97 k_{1}\right) \mathrm{h}^{-1}$.

Unlike predictive models that attempt to describe the lag phase using an adjustment function (Baranyi et al., 1993), this model predicts the transition from lag phase to exponential growth phase with an empirically determined

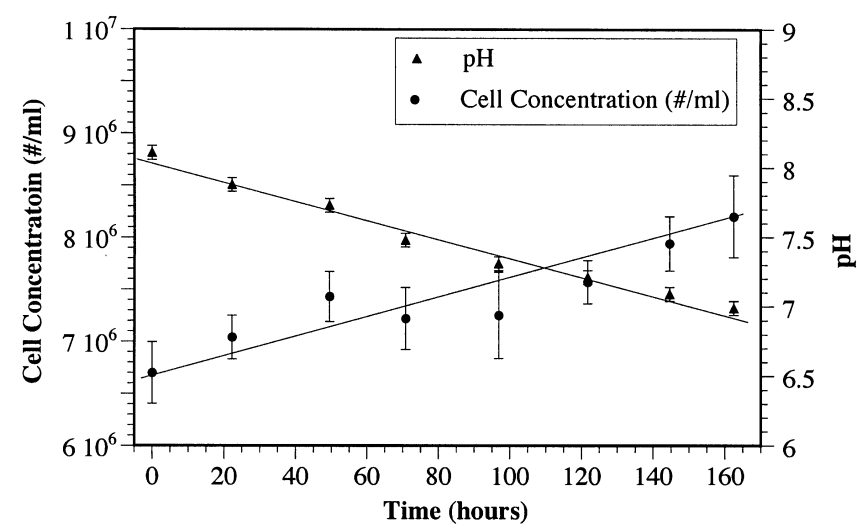

Figure 5. Lag phase growth for a typical batch reaction. Error bars indicate $95 \%$ confidence intervals. 


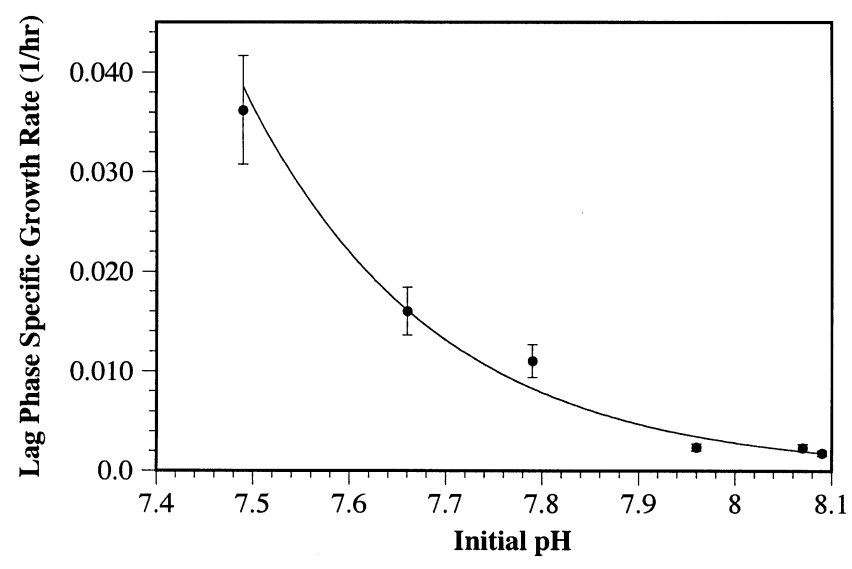

Figure 6. Lag phase specific growth rate decreases exponentially with increasing initial $\mathrm{pH}$. Experiments were performed in duplicate. Error bars indicate $95 \%$ confidence intervals.

growth parameter. Growth during the exponential growth phase and the subsequent stationary phase was assumed to follow logistic growth kinetics (Fogler, 1999), where the maximum cell concentration varies according to the initial cell concentration, and was determined from experiments:

$$
\begin{gathered}
r_{x}=\frac{d C_{x}}{d t}=\mu C_{x}\left(1-\frac{C_{x}}{C_{x \max }}\right)^{n}, \\
\text { with } \mathrm{n}=1
\end{gathered}
$$

where $C_{x \text { max }}=52.46 C_{x \text { initial }}$.

The specific growth rate observed during the exponential growth phase was determined from a series of batch experiments conducted in a previous study. The substrateinhibited specific growth rate law and rate constants were determined previously by Wolf and Fogler (2001):

$$
\mu=\frac{\mu_{\max } \cdot C_{S} \cdot e^{\left[-\left(C_{S} / K_{i}\right)^{2}\right]}}{K_{m}+C_{S}}
$$

where $K_{i}=389 \mathrm{~g} / \mathrm{L}, \mu_{\max }=1.39 \mathrm{~h}^{-1}$, and $K_{m}=1.29 \mathrm{~g} / \mathrm{L}$.

The production of $\mathrm{H}^{+}$during the exponential growth phase was growth-associated. Regardless of the initial $\mathrm{pH}$, the rate of production of metabolites was a linear function of the instantaneous specific growth rate:

$$
\frac{d C_{H^{+}}}{d t}=k_{3} \frac{d C_{x}}{d t}
$$

with $k_{3}=1.17 \times 10^{-13}\left[H^{+}\right] / \mathrm{mL}$.

Table I. Suboptimal $\mathrm{pH}$ growth model results.

\begin{tabular}{ccc}
\hline Initial $\mathrm{pH}$ & Observed lag time $(\mathrm{h})$ & Model lag time $(\mathrm{h})$ \\
\hline 7.66 & $40.1 \pm 10.2$ & 34 \\
7.79 & $71.8 \pm 4.3$ & 64 \\
7.90 & $110.0 \pm 12.0$ & 101 \\
8.10 & $195.5 \pm 15.0$ & 188 \\
\hline
\end{tabular}

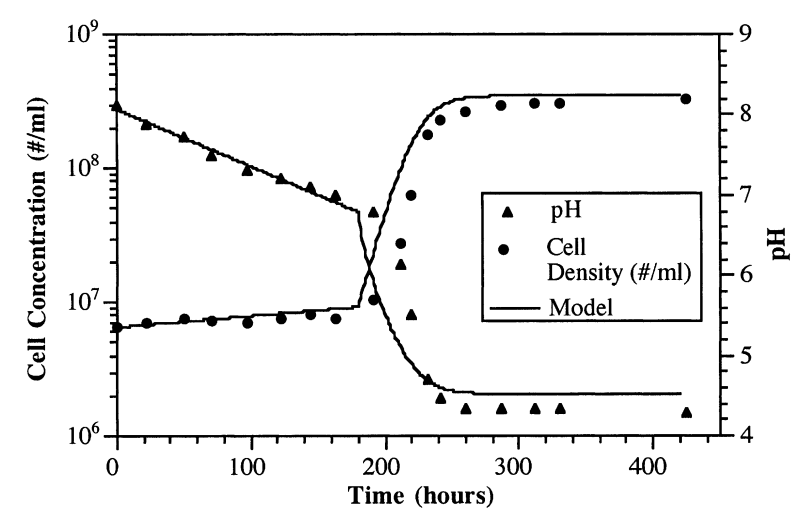

Figure 7. Model predictions for cell concentration and $\mathrm{pH}$ for an initial $\mathrm{pH}$ of 8.10 and an initial cell concentration of $6.4 \times 10^{6}$ cells $/ \mathrm{mL}$.

The rate of substrate consumption is given by the following relation:

$$
\frac{d C_{S}}{d t}=-\frac{1}{Y_{X S}} \frac{d C_{x}}{d t}
$$

where $Y_{X S}=4.9 \times 10^{6}$ cells $/ \mathrm{g}$ sucrose.

The sucrose yield was calculated from experimentally determined cell and sucrose concentrations measured during the exponential growth phase.

The batch growth model, consisting of Eqs. (3)-(8), predicted lag times for a variety of initial suboptimal $\mathrm{pH}$ values. By varying the initial $\mathrm{pH}$ and keeping all other parameters constant, the model predicts $\mathrm{pH}$ and cell concentration curves as a function of time. Within the suboptimal $\mathrm{pH}$ range, the predictive model and experimental lag times are in agreement, as can be seen in Table I. Shown in Figure 7 is a representative comparison between the model and experimental data for an initial $\mathrm{pH}$ of 8.10 and an initial bacterial concentration of $6.4 \times 10^{6}$ cells $/ \mathrm{mL}$.

\section{CONCLUSIONS}

Although the lag phase is often a variable feature of the bacterial growth curve, this study has shown the lag phase can be controlled with precision. When inoculated into an alkaline growth medium with a low $a_{w}, L$. mesenteroides can ameliorate the medium through acid production. There is a critical $\mathrm{pH}$ of $6.79 \pm 0.06$ at which exponential growth began, regardless of the initial suboptimal $\mathrm{pH}$. The duration of the lag phase can be predicted if L. mesenteroides is grown in a medium with an initial $a_{w}$ of 0.960: the batch growth model has verified that cell concentration, solution $\mathrm{pH}$, and lag times can be predicted when the medium conditions change as a function of time. Because L. mesenteroides has effective mechanisms to compensate for unfavorable growth conditions, it may be possible to observe a critical $\mathrm{pH}$ phenomenon in other acidophiles inoculated into an alkaline medium. 


\section{References}

Atlas RM, Bartha R. 1998. Microbial ecology: fundamentals and applications. Menlo Park, CA: Benjamin/Cummings. 694 p.

Baranyi J, Roberts TA, McClure P. 1993. A non-autonomous differential equation to model bacterial growth. Food Microbiol 10:43-59.

Brading MG, Jass J, Lappin-Scott HM. 1995. Dynamics of bacterial biofilm formation. In: Costerton JW, editor. Microbial Biofilms. Cambridge: Cambridge University Press. p 46-63.

Cerf O, Davey KR, Sadoudi AK. 1996. Thermal inactivation of bacteria: a new predictive model for the combined effect of three environmental factors: temperature, $\mathrm{pH}$ and water activity. Food Res Int 29:219-226.

Christian JH, Hall JM. 1972. Water relations of Salmonella oranienburg: accumulation of potassium and amino acids during respiration. J Gen Microbiol 70:497-506.

Cooper S. 1991. Bacterial growth and division: biochemistry and regulation of prokaryotic and eukaryotic division cycles. San Diego, CA: Academic Press. 501 p.

Cusack F, Lappin-Scott HM, Costerton JW. 1987. Bacteria can plug waterflood injection wells. Oil Gas J 85:59-64.

Dilworth MJ, Glenn AR, Foundation N. 1999. Problems of adverse $\mathrm{pH}$ and bacterial strategies to combat it. In: Chadwick DJ, Gardew G, editors. Bacterial responses to $\mathrm{pH}$. Chichester, UK: John Wiley \& Sons. p 264.

Fogler HS. 1999. Elements of chemical reaction engineering. Upper Saddle River. NJ: Prentice Hall. 967 p.

Gouffi K, Pichereau V, Rolland JP, Thomas D, Bernard T, Blanco C. 1998. Sucrose is a nonaccumulated osmoprotectant in Sinorhizobium meliloti. J Bacteriol 180:5044-5051.

Harris DC. 1987. Quantitative chemical analysis. New York: WH Freeman \& Co. 818 p.

Harvey RW, Garabedian SP. 1991. Use of colloid filtration theory in modeling movement of bacteria through a contaminated sandy aquifer. Environ Sci Technol 25:178-185.

Holzapfel WH, Shillinger U. 1981. The genus Leuconostoc. In: Starr MP, editor. The prokaryotes: a handbook on habitats, isolation, and identification of bacteria. Berlin: Springer. p 1508-1534.

Jang L-K, Chang PW, Findley JE, Yen TF. 1983. Selection of bacteria with favorable transport properties through porous rock for the application of microbial-enhanced oil recovery. Appl Environ Microbiol 46:1066-1072.

Jenneman GE, Knapp RM, McInerney MJ, Menzie DE, Revus DE. 1984. Experimental studies of in-situ microbial enhanced oil recovery. Soc Petrol Eng J 24:33-37.

Kalathenos P, Baranyi J, Sutherland JP, Roberts TA. 1995. A response surface study on the role of some environmental factors affecting the growth of Saccharomyces cerevisiae. Int J Food Microbiol 25:63-74.
Kim DS, Fogler HS. 2000. Biomass evolution in porous media and its effects on permeability under starvation conditions. Biotechnol Bioeng 69:47-56.

Lappan RE, Fogler HS. 1992. Effect of bacterial polysaccharide production on formation damage. SPE Product Eng 7:167-171.

Lappan RE, Fogler HS. 1994. Leuconostoc mesenteroides growth kinetics with application to bacterial profile modification. Biotechnol Bioeng 43:865-873.

McMeekin TA, Olley JN, Ross T, Ratkowsky DA. 1993. In: Sharpe AN, editor. Predictive microbiology: theory and application. Taunton, Somerset, UK: Research Studies Press. 340 p.

Pichereau V, Hartke A, Auffray Y. 2000. Starvation and osmotic stress induced multiresistances: influence of extracellular compounds. Int J Food Microbiol 55:19-25.

Press WH, Flannery BP, Teukolsky SA, Vetterling WT. 1992. Numerical recipes in $\mathrm{C}$ : the art of scientific computing. Cambridge: Cambridge University Press. 994 p.

Presser KA, Ratkowsky DA, Ross T. 1997. Modelling the growth rate of Escherichia coli as a function of $\mathrm{pH}$ and lactic acid concentration. Appl Environ Microbiol 63:2355-2360.

Raiders RA, McInerney MJ, Revus DE, Torbati HM, Knapp RM, Jenneman GE. 1986. Selectivity and depth of microbial plugging in Berea sandstone cores. J Indust Microbiol 1:195-203.

Robertson EP. 1998. The use of bacteria to reduce water influx in producing oil wells. SPE Prod Facil 13:128-132.

Sarkar AK, Georgiou G, Sharma MM. 1994. Transport of bacteria in porous media: I. An experimental investigation. Biotechnol Bioeng 44:489-497.

Scott WJ. 1953. Water relations of Staphylococcus aureus at $30^{\circ}$ C. Austral J Biol Sci 6:549-564.

Taylor SW, Jaffé PR. 1990. Biofilm growth and the related changes in the physical properties of a porous medium. I: Experimental investigation. Water Res Res 26:2153-2159.

Wilderer PA, Characklis WG. 1989. Introduction: structure and function of biofilms. In: Characklis WG, Wilderer PA, editors. Structure and function of biofilms: report of the Dahlem workshop on structure and function of biofilms, Berlin, 1988, November 27-December 2. New York: John Wiley \& Sons. p 387.

Willhite GP. 1986. Waterflooding. Richardson, TX: Society of Petroleum Engineers. 326 p.

Wolf BF, Fogler HS. 2001. Alteration of the growth rate and lag time of Leuconostoc mesenteroides NRRL-B523. Biotechnol Bioeng 72: $603-610$.

Zwietering MH, Jongenburger I, Rombouts FM, Van'T Riet K. 1990. Modeling of the bacterial growth curve. Appl Environ Microbiol 56: $1875-1881$. 